\title{
The Patterns of Memorizing Qur'an for Primary School Students and the Management of Pesantren Tahfidz
}

\author{
A. Zaenurrosyid*, Abdul Kahfi, Hidayatus Sholihah \\ Sultan Agung University, Semarang \\ *Corresponding Author: Zaenurrosyid79@gmail.com
}

\begin{abstract}
The world of pesantren is an educational learning environment that effectively shapes the thinking and mentality of students effectively. Complete physical facilities such as buildings, learning environment, complete curriculum and human resources (asatidz) to accompany 24 hours intensively. The students are also protected from the tendency of social media to have a negative impact during their debriefing and learning. Pesantren Madinatul Qur'an located in Pecangaan, South Java Pesisiran is interesting to study because of the integration of educational institutions with the provision of Tahfidz Al-Quran for children and formal education both at madrasah ibtidaiyah or at equality schools. This study applies the perspective of management of Pesantrens which is approached qualitatively. Some of the informants as primary data sources are the founders and administrators of the pesantren. The data were collected through the method of observation, in-depth interviews, and observations at the pesantren. Another method is collecting documentation as a secondary data source. From various analyzes of the data in this study, it was found that the application of the innovative method of asatidz in the memorization pattern of elementary school children was found. The management pattern of the pesantren is managed professionally with support from various parties, especially on the side of the pesantren's facilities and appreciation for human resources. The presence of superior teachers, especially in the field of tahfidz, intensively accompanying students to become a support system for the excellence of the achievements of students at the Madinatul Quran Pati Selatan pesantren.
\end{abstract}

Keywords: Children's Tahfidz Pesantren, Professional Management, Curriculum Integration.

\begin{abstract}
Abstrak
Dunia pesantren merupakan lingkungan pendidikan efektif yang membentuk pemikiran serta mentalitas santri. Kelengkapan fasilitas baik bersifat fisik seperti gedung, lingkungan pembelajaran, kelengkapan kurikulum serta SDM (asatidz) yang mendampingi 24 jam secara intensif. Para santri juga terjaga dari kecenderungan media sosial yang berdampak negatif di dalam masa pembekalan dan pembelajarannya. Pesantren Madinatul Qur'an yang berada di Pecangaan, Jawa Selatan Pesisiran ini menarik untuk diteliti karena keterpaduan lembaga pendidikan dengan pembekalan Tahfidz Al-Quran bagi anak-anak dan pendidikan formal baik di madrasah ibtidaiyah ataupun di sekolah kesetaraan. Penelitian ini menerapkan perspektif manajemen pendidikan pesantren yang didekati secara kualitatif. Beberapa informan sebagai sumber data primer adalah para pendiri dan pengurus pesantren. Data diambil melalui metode observasi, wawancara mendalam, serta observasi di pesantren. Adapun metode lainnya adalah pengumpulan dokumentasi sebagai sumber data sekunder. Dari berbagai analisis data-data dalam penelitian ini, ditemukan penerapan metode inovatif dari asatidz di dalam pola menghafalkan Quran anak SD. Pola manajemen pesantren dikelola
\end{abstract}


secara profesional serta dukungan berbagai pihak terutama pada ada sisi fasilitas pesantren dan apresiasi bagi para SDM. Hadirnya para pengajar unggul khususnya pada bidang tahfidz secara intensif mendampingi santri menjadi supportsystem atas keunggulan prestasi santri di pesantren Madinatul Quran Pati Selatan ini.

Keywords: Pesantren Tahfidz Anak, Manajemen Profesional, Integrasi Kurikulum.

\section{Introduction}

Pesantren is a form of traditional education that still exists and is the spearhead of the Islamic education process in Indonesia. Pesantren as an educational institution then grows and develops in the tradition of religious education in society and has an important meaning so that its existence continues to be fought for. The role of pesantren as Islamic educational institutions in Indonesia is currently required to be able to participate in efforts to build Indonesian people who are physically and mentally strong, have quality, have good character and are useful for life. Missionary Pesantrens have goals that must be carried out, such as instilling faith in students, fostering enthusiasm and attitudes to practice Islamic teachings, fostering tolerance between religions and having a humanist feeling among each other (Yumnah, 2020).

Thus the position of pesantren is not only understood as an Islamic educational institution but also understood as an educational institution that shapes students religiously, has good morals and also fosters love (humanism) for all levels and plays a role in society. In essence, pesantren in general not only teaches knowledge as material, or skills as a religious activity, but also relates everything to practice (amaliah) that has values and morals (Hannan, 2018).

However, in turn, pesantren experienced a problem of dualism. This is not only about the teaching system but also the management. This tends to open gaps in it. Moreover, based on the 2003 Law concerning the National Education System, it mandates that funding for educational institutions is the responsibility of the central government, local governments and the community. To finance it, the central and local governments must allocate at least $20 \%$ of the annual budget (APBN / APBD). This includes financing investment, operational and personnel costs. The education allocation is $20 \%$ of the APBN expenditure, which is around Rp. 492.5 Trillion. 
The direction of the Indonesian government policy regarding education financing is intended for effectiveness and BOS, the smart Indonesia program, accelerated development of school and university sarpras, student scholarship (Bidik Misi programs), research endowments, enforcement of education budget fulfillment by the local government and strengthening vocational education to increase link and match with industry. The education budget through central government spending consists of the education budget at the State Ministries or Institutions (K / L) of Rp. 153,726 trillion, and the education budget for BA BUN is Rp. 9,363 Trillion.

The ministries that manage educational institutions consist of the Ministry of Religion who gets and Rp. 51,896 trillion, then the Ministry of Research, Technology and Higher Education with Rp. 40,210 trillion, and the Ministry of Education and Culture with Rp. 35,993 trillion. This education budget is allocated through the financing of the national education development fund of Rp. 20 trillion and a research endowment of Rp. 990 billion.

From government data regarding the financing of these educational institutions, it turns out that what pesantren feels is still overlapping. The acceptance of pesantren funding is still from student guardians, the community, zakat funds, donations, alms and waqf so that the existing management can be more organized and get more attention from the central government funding channels. This will also have an impact on the improvement and development of pesantren in the future (Mubarok, 2020).

The dynamics of student learning, especially in the tahfidz pesantren for early childhood, are rare in various regions in Indonesia context. For example, Pesantrens which are supported by a good management pattern with adequate funding support from donations and public social institutions that are concerned with the world of Islamic education. Pesantren Madinatul Quran, which is located in the southern district of the Java North Pesisiran area, is very important and contributive to the character building of the younger generation in exploring and providing a variety of references to learning models for students, especially in the world of education. 
This paper is a discussion using qualitative methods. This method was chosen with the consideration that the research procedure, including the form of analyzes that resulted from field data will be discussed descriptively. This research was conducted through an inductive approach in the field, so that it was compiled descriptively according to the facts in the field. From the results of this study, the author does not only act as an instrument, but as an observer during the data collection process in the field. The study of this discussion takes the object of research studies at Madinatul Qur'an Pesantren, Central Java. The source of this data is the subject There are two data that have been taken by pesantren, both data in the form of primary data and secondary data.

The data records obtained are the results of direct observation of the activities of the students as well as the teaching and learning activities of the students as well as participating in observing the activities of the students in it so that the qualitative data obtained is likely to be more accurate and valid. The interview method is applied as part of the method carried out in the form of asking questions orally in the hope that the interviewed informants are willing to provide accurate and good answers to various data needed.

In this interview there is a reciprocal interaction between the researcher and the subject. Researchers give questions and subjects answer so that questions and answers are created that produce concrete data. Other documentation data is searched through variable notes, archives, book documents, newspapers, journals, transcripts, minutes, agenda of activities and so on (Arikunto, 2010). This effort was carried out in order to find data on matters relating to the object of research in the form of notes, archives and documents related to activities that support the memorization of students at Pesantren Madinatul Qur'an in Central Java.

Data analysis in this stage is carried out by searching and arranging data in the form of notes on the results of observations, as well as interviews that are arranged in a sequential and systematic manner so as to increase understanding of the object of study being analyzed, and present it as new findings for other parties. As for improving this understanding (Muhadjir, 1998) states that analysis needs to be continued by trying to find meaning. In this case, Miles and Huberman describe 
that qualitative data analysis is carried out through three channels, namely data reduction, data display and drawing conclusions.

\section{Pesantren, Management, and Its Comprehensive Steps}

Human resources management is the utilization of human resources to achieve organizational objectives (Mondy, Noe, and Premeaux, 1999). It is dynamic assistance in the stages of recruiting $\mathrm{HR}$, selecting and placing by providing training and programs of innovations in HR empowerment to achieve goal setting forming personalities (Handoko, 2001). Its goal of increasing the contribution of human resources in an institution or institution in order to achieve the level of productivity of an institution by providing an effective and effective work unit (Soekidjo, 1998), with the aim that every institution or any institution has social obligations that must be fulfilled (Siagan, 2003). So, to fulfill this social responsibility, the institution or institution must have social sensitivity so that it is able to make real contributions to the surrounding community.

The functional objective of human resource management in this area is a comprehensive step in a variety of procedures that are carried out in a unity of performance in developing HR governance within the institution with the hope of being able to contribute optimally. Thus, it becomes clear that each element in the institution is responsible for its respective functions.

Objectives Personnel are expected to provide assistance for the workforce to achieve individual goals, in a more macro scope, namely institutional achievements. Thus, every workforce should have their goals fulfilled as the achievement of motivation and maintenance of their enthusiasm. In this case, (Armstrong, 2003) argues that specifically human resource management has the aim of making the institution or institution able to obtain and maintain HR as needed by institutions, namely HR who has good skills, quality quality. Developing management practices that are highly committed and positioning employees as stakeholders for the institution or institution is considered capable of encouraging cooperation and mutual trust between them.

Creating an institutional climate or institutions can maintain productive and harmonious relationships. Develop an environment that is highly conducive to 
developing teamwork and flexibility. Helping institutions or agencies harmonize stakeholder needs. Ensure that human resources are rewarded based on their performance and performance. Organizing a diverse workforce taking into account individual and group differences in placement and work styles. Ensuring equal opportunities exist among all employees. Manage human resources using an approach to fairness and transparency. Maintain and improve the physical and mental well-being of human resources.

Several past-oriented performance appraisal methods such as rating scales and checklists or checklists and ways of assessing work have a forward orientation in giving self-value and psychological values. Rating scale, in this case the rater measures the work performance of employees from the lowest to the highest scale, comparing the work results of teachers or employees with predetermined criteria. Checklist or checklist, in this method the assessor selects only statements (items) that are already available and describes the work performance and characteristics of the employees being assessed. If the statement is prepared carefully and its validity and reliability are tested, then this tool will be able to provide an overview of the performance of teachers or employees carefully.

Self-assessment (self appraisal), this method emphasizes the performance appraisal of teachers or employees carried out by themselves with the aim of selfdevelopment in the framework of institutional or organizational development. The involvement of teachers or employees in their commitment to performance improvement process is the most important dimension of this self-assessment. Psychological assessment is carried out by involving a psychologist. The method often used is psychological tests that measure intellectual aspects. Motivation, emotions, etc. from the teacher or employee concerned (Mangkuprawira, 2003).

The essence of education in Pesantren is closely related to the objectives of the Pesantren through its mission. In order to realize this essence, of course, requires a quality operational instrument which is constantly developed in accordance with the progress of the times and the needs of society. For example, through the improvement of various components such as curriculum and methodology development, compliance. Needs and improving the quality of the ability of teaching 
staff, facilities and infrastructure. Pesantren as Islamic education institutions can always compete with other educational institutions.

There are several elements of education that must be fulfilled so that the objectives of the Pesantren can achieve all of these, meaning that the Pesantren by maintaining the trust of the guardians to guide and prepare children, with the permission of Allah Taala, cultivates a generation of qurani. The purpose of education and guidance that is carried out is so that children will be able to benefit the environment in carrying out the functions of khalifah fil ardh and their responsibilities towards God Almighty while still adhering to the Al-Qur'an. Given the position and position of the Pesantren, of course this is a responsibility for every element involved in it.

The Pesantren's efforts in finding a role for the rote method will be adjusted to basic needs, at least three approaches are offered as alternative patterns of Pesantren education. First, through a systemic approach, namely changes must be made to the entire system at the existing Pesantren, in the sense that there is a total change. Second, the supplementary approach, namely by adding a number of educational packages aimed at broadening the understanding and appreciation of Islamic teachings more adequately. Third, the complementary approach, namely by changing the curriculum to be integrated in an integrated manner oriented towards knowledge competencies, skills, ability competencies (having certain abilities), socio-cultural competences, and divine spiritual competences.

From the description above, it is emphasized that Islamic education institutions, especially Pesantren, must design alternative memorization models that are in line with the needs of today's developments. It is hoped that with this method Pesantrens can face and answer the challenges of changes that occur in social and cultural life towards a new Indonesian society. Borrowing the essence of Islamic education used by Hasim Amir, that education is idealistic, is education that is integralistic, humanistic, pragmatic and rooted in strong culture.

Compensation is an important component in its relationship with employees. Compensation is a right that must be given to employees. Compensation is a reward that employees can respond to positively after employees are able to carry out their duties properly. Meanwhile, according to (Mondy, Noe and Premeaux, 1999), 
"Compensation is the total of all rewards provided by employees in return for their labor." Compensation is all awards given to employees in return for work that they have done. From the above understanding, it can be seen that the provision of compensation is not only in the form of finance, such as giving bonuses, social subsidies, pensioners, educational scholarships, both material and financial, such as the comfort that workers get both psychologically and psychologically in the workplace environment.

The objectives (Notoatmodjo, 1998) of this compensation system are given with the objectives, among others, to respect work performance, retain employees, improve work quality and increase time discipline. With the compensation provided by a good and satisfying institution or organization as remuneration for the work performance of employees, it will encourage employee behavior as expected by the institution. Guaranteeing justice, with compensation that is in accordance with their function, position and work performance will ensure justice that is obtained by employees in the institution.

\section{Offers Learning Models in Modern Islamic Education}

Hasim Amir, as stated again by Malik Fadjar, offers a conception of education based on Islamic values, in adopting various social changes in the Indonesian context by means of, First, through an integrated education model, which is a form of education in various fields of competence that include; divinity (rabbaniyah), humanity (insaniyah) and alamyah, as a comprehensive pattern in the whole of a comfortable life in realizing rahmatan lil 'alamin. In the form of education that sees the human side as a personality consisting of physical-spiritual elements, has intellectual power, feelings, both social and individual activities.

Integrated education has an orientation in educating santri or students with good integrity, is grateful for having a high sense of godliness, and contributes

greatly to society. This sustainability culminates in the process of eliminating social disintegration, and being able to unite oneself with nature so as not to cause damage, but to protect, maintain, empower and optimize the potential of nature according to human needs. 
Second, through a humanist education model, which aims to humanize humans, namely God's creatures with their fame. As individuals, humans are able to carry on, maintain and develop their life. With the education model it can build a humanization process, presumably it can learn to respect human rights, such as the right to apply and be treated fairly, the right to speak the truth, and the right to exercise compassion. It is not surprising that humanistic humans are also formed by humanistic education, with an orientation in fostering patterns of thought, sensitivity, and self-will in acting in accordance with norms and teachings originating from humanistic mulya which gives control to individual characteristics, ego, egocentric value with a sense of cherishing others. The form of respect and respect, the form of feeling to give and receive, the nature to help each other and even the willingness to build an attitude of tolerance with a willingness to respect the various differences that exist.

There is a third model of the education model that has been initiated, namely the education model that considers humans to be considered as creatures who always need to live in their lives to survive and even develop themselves in social life and physical also in spiritual growth. These needs such as the need for selfactualization, the need to have sensitivity and the need to live in comfort, justice and other needs spiritually. This type of education is intended to build a pragmatic personality who has self-awareness of his life survival needs, builds a humanitarian personality that is sensitive and contributive, so that he will be more resilient in carrying out his life normally in society.

Another model of education is educating with reasoning in culture, namely a form of education that has strong roots of welfare, both human and cultural materials in a community, as well as groups in the social environment. Education that is modeled on this culture is expected to have an output formation on selfconfidence in building a civilization based on its own cultural heritage.

Even so, an educated person does not mean to have an anti-reform mentality and even against the progress of the times, but this kind of educational personality is expected to be able to produce an adaptive person. A person who is transformative for cultures that develop from externals. Thus, this person becomes a human being who is adaptive to the times, able to have a strong social sensitivity 
and to survive in his life. Of these various models or forms of education, education that is based on Islamic values developed in Islamic educational institutions has more opportunities to build the character of students who excel in global competition.

In an educational model that is based on Islamic values from several educational institutions, both honed educational institutions or integrated school education, it prefers a school curriculum that is integrated with general material and religion, meaning that children are provided with comprehensive educational materials both at mental or physical as well as. Islamic thinkers, Fazlur Rahman who argued that the modern school education model could be integrated into the concept of education in the curriculum of Islamic institutions so that it could spark a generation of strong young Muslim intellectuals.

Religious education that has developed a lot today constructs a strong and quality Islamic education model in the formulation of a futuristic vision and mission in the context of pesantren in or better known as santri, who have the need to respond and prepare themselves when they finish education at the pesantren to back into society. The santri already have the ability to adapt and even educate a social society that is constantly changing. The learning model that is aimed at always finding solutions to the problems of the people and society does not then stop at the monologue side of educational capital.

The form of education that is more of a professional educational management system with teaching resources, namely teachers who have the ability to professionalism themselves, according to their competence in Pesantrens. In this positioning, the institution should have the readiness to educate quality generations of course with the addition of various curricula and additional skills in the educational design that is encouraged. Curriculum construction or educational formations raised are conceptual forms of Islamic teachings adapted to the context of socio-cultural development.

Character education and religious content lately for students in schools has become a strong problem in the conversation of parents. Education refers more to the basis of education with family and and education on a community basis can be applied massively through pockets of educational institutions such as Pesantrens or 
educational institutions that are concerned with character competence and moral content in the personal of students. In the teaching and learning process in the pesantren environment, exemplary behavior is needed, namely strengthening on the psychomotor or affective side and not only strengthening the cognitive side alone or knowledge that is tested cognitively, it also means that additional models are needed in the form of strengthening understanding in students and it is developed in the world of pesantren at a further stage.

Education actually has a main orientation in dialoguing the understanding needs of students with the social environment or with the nature where they live. For a strong person who is able to overcome life's challenges or any problems that arise in his own, social and family life. So education actually has a function to be a bridge to understand the person about the life he lives. Such education requires training in closeness to heart, education that also connects individuals with their environment. Such a model is also capable of being the design and capital of Islamic education in building a new paradigm to educate and teach generations in the midst of global changing times.

Pesantren can be designed like miniature houses, learning spaces such as schools and social media, where students play is an environment that is conducive to building the practical needs of students when they need training in finding challenges and solving future life problems in the community. Especially in the development of the digital age of Islamic education should offer more innovative concepts to Islamic education institutions and especially pesantren in strengthening the integrity and mentality of the santri.

Today's educational institutions are indirectly a learning space that provides provision in strengthening the professionalism of their students (santri) with mastery of the skills needed to be able to survive in later life. The social and cultural environment has changed in such a way, so the models and styles of education offered to the current generation of Islam should also have the driving force to make adaptive education in accordance with the needs of society both on the political economy side or mastery of science, science and technology.

Classical models in education can of course still be used in terms of wisdom, very strong ethical contents, also on the side of teaching how children build 
persistence, discipline, and even how to then educate children in forming mutually exclusive characters. However, the development of the current millennial era, it is not enough to face it by equipping students through classical methods or forms, normative methods, but the current era as education experts state, is education that collaborates various disciplines, integrated educational curriculum with various aspects that strengthen completeness in educating students or santri.

\section{Management of Pesantren Madinatul Qur'an}

The historical movement of the establishment of the Pesantren Madinatul Qur'an was initiated by the decline of a South Pati Ibtidaiyah Education Institute, to be precise in Winong village, Winong district, Pati regency. An old educational institution at that time in 2008 the number of students lived was approximately 67 students and was informed that a year later from the Indonesian Ministry of Religion, there would be school accreditation, where the accreditation process if the number of students was less than the educational standard, it was considered an educational institution. it is not appropriate to organize an educational program.

In such conditions the management of the Tarbiyatul Islamiyah foundation which oversees the madrasa sees it necessary to reorganize so that there is a rejuvenation of management and at that time the average ranks of the board of management are old. Several months before the reorganization took place, it seemed that the principal had read the situation in which if this institution did not change its management, the future hopes for progress seemed difficult.

He thought of Faiz Al Muktabar as the principal of the MI school at that time to hold a farewell agenda for grade 6 graduates. With a neatly arranged event design and assisted by the entire teacher council. Pak Faiz hopes to get sympathy from the community leaders who were invited to the event. Among them were Mr. Tri Handoko as one of the invitees who had a background in traders who were deliberately invited by Mr. Faiz to attend the farewell ceremon

On that occasion, when the event had started, Mr. Faiz deliberately came over to Mr. Kokok (Tri Handoko's nickname) took the position of sitting side by side, jagong and telling stories, about the enthusiasm of teachers and children in 
struggling to maintain the existence of educational institutions to keep going. In the current condition, there was not enough support from the village community.

From the many stories that Pak Faiz told, it touched Mr. Kokok's heart to be involved in the struggle process to help teachers maintain the sustainability of the institution so that it can be maintained. The reorganization process that had been discussed was finally getting a picture of the leadership figure who was expected to be invited to fight to bring the educational institution forward.

The reorganization took place and the members agreed to ask Mr. Kokok to be willing to take control of the chairman of the Tarbiyatul Islamiyah Foundation at that time in 2009 - 2014. With a little management capital that he had from his experience in managing a business, Mr. Kokok began to make some fundamental changes that had not been thought of.

So representatives of the teacher council gathered with the principal and also some of the board of directors of the foundation to be invited to discuss. Finally, several policies emerged, including performing the duha prayer before entering school and the midday prayer in congregation at the mosque with all the students and teachers. Incorporating the TPQ curriculum which was previously carried out in the afternoon outside school hours, which was finally changed to include it in class hours, and closed with Asr prayers in congregation. So that the tahfidz Qur'an is held, which targets one juz a year.

With the emergence of the tahfidz program, Mr. Kokok and Ust. Faiz were required to find a teaching teacher in their field, namely tahfidz quran. The process runs by contacting some acquaintances to get references from teachers with a background of a quran memorizer. He came together at a house in Kebowan Village, his name is Kyai Jabir Al Hafidz. From his reference, Mr. Kokok and Ust. Faiz were told to go to visit Kyai Winarno Al-Hafidz's village.

There are three person; Mr. Kokok and Ust. Faiz met with Kyai Winarno AlHafidz at his house. Kyai Winarno finally accepted the result of the friendship and the intention of the invitation to join the struggle together to educate children in memorizing the quran. Then he was asked to be the coordinator of the quran recitation teachers at the Winong Ibtidaiyah Madrasah school. Unexpectedly, it turned out that the three pillars of the fundamental changes that were made after a 
year of traveling finally brought extraordinary changes. The number of students increases significantly each year until there are parallels in each class. Of course, with strict escort together with the teacher council builds a commitment to always go forward.

The journey of struggle flows. It turns out that from this process there are several guardians who have special attention to the memorization of their children. From some of the guardians submitted a proposal to the head of the foundation, that the tahfidz program be increased not only for one juz one year, but if possible 30 juz at all. Mr. Kokok, as the head of the foundation, responded to this proposal by gathering all the guardians to explore the level of interest of the guardians in the 30 juz tahfidz program, which consequently must be done by means of a boarding school.

Since the gathering of the guardians, it turns out that there are 25 guardian students who responded to the 30 juz tahfidz program with boarding school. Seeing the reality, Mr. Tri Handoko as the head of the foundation, Mr. Faiz Al Muktabar as the principal and Kyai Winarno as the tahfidz coordinator, the three of them walked together to one of the empty classrooms on the second floor and took a sitting position facing each other, the three of them contemplating while feeling the direction of the journey of struggle arranged by Allah SWT, in the reflection he three analyzed as if Allah will want the establishment of Pondok Tahfidz Qur'an in Desa Winong, Pati.

Finally, the three of them are determined, the three of them do not want to be left behind in the process of erecting the boarding school which is desired by Allah SWT. Finally, the three of them reached out their hands and shook hands to pledge a sacred promise addressed to Allah SWT with the words of bismillahirrahmaanirahim. The three of them were ready to begin the establishment of a boarding school with the name Madinatul Quran. A name proposed by Ust. Faiz with the consent of Mr. Koko and Mbah Win (his familiar name). With 25 students and their facilities, Madinatul Quran boarding school was finally established in Cangaan Village, Winong District, Pati District until now.

With the rapid development of this Pesantren, it has now established various levels of madrasah equality with adequate facilities, in addition to geung facilities 
and equipment for Pesantren and learning buildings. As for the total number of students in Pesantren Madinatul Quran is now from class 1 to grade 8, namely class 1 , male 3 people, female 11 people, a total of 14 students, class 2 male 15 people, female 10 people, number of 25 point students as for class 3 males 11 females 14, a total of 25 point students as for class 4 males 17 females 6, a total of 23 point students 5 class males 21.0 females 15, a total of 36 students grade 6 females 11 males 7 total a total of 187 males 9 females 8 total totals of class 7 are 17 Santri; 8 total male students and female 73 total 81 students. And the total number of students of Madinatul Qur'an is 165 students.

These students come from sharing the region in Indonesia with the variety of habits and patterns of interaction of students. However, when they are in Pesantren and engrossed in the process of memorization and learning and interacting with friends in Pesantren they unite and in fact they help each other and appreciate each other with the guidance of the ustadz-ustadzah who accompany them both in the Pesantren and when the students are in the study rooms in the madrasah classes diniyah with the subjects studied.

As stated by Faiz Al Muktabar as one of the pesantren caregivers (2020), the development of this pesantren is progressing rapidly, in addition to the construction of buildings and physical facilities of the pesantren, as well as the development of human resources in its management. This human resource includes teaching teachers and caretakers at the pesantren as well as other human resources who help meet the needs of students, both laundry, meeting the nutrition of students, and other institutional needs. This pesantren is only supported by funding that comes from students, but there is also a larger funding support that supports it.

The funding allocation for this pesantren is distributed to the physical construction of the pesantren building, dormitories, and other facilities. Other funding supported by the KIIITA institution (an institution that focuses on ZISWAF) is assisted in funding the education of underprivileged students (delivered by Kukuh as one of the founders of the Pesantren Madinatul Quran, 2020). Thus there are many different sources of funding for the progress of this pesantren, in addition to donors general, also sourced from infaq alms funds and grants from wealthy people, 
The Patterns of Memorizing Quran ...

generous people who have sympathy and concern for the development of Pesantrens.

\section{The Patterns of Tahfidz Learning in Pesantren Madinatul Quran}

The memorization method in Pesantren Madinatul Quran is divided into several main roads in the class system system according to the stages that have been memorized. There are now in grade 1, grade 2 and grade 3 and grade 4 in grade 1, students are expected to be able to master 1-1005 in grade 21 to 101 to 15 and grades 4 1-20 As for grades 5 and 6 they still join the Islamic Tarbiyatul Islamic Madrasah, they continue to follow subjects in MI in the morning and in the afternoon and evening at the Pesantren

With various evaluations that have been carried out by the food caregivers, the santri always deposit 1 juz to their teacher and from the increase from J1 to juz up to juz 2 up to juz 30 minutes, fifth they apply the majelisan system of 1 to 5 juz when then they have deposited the increase. It is relatively more controlled and he is active if they deposit, the lecture assembly is 5 juz a day and 10 juz a day until now at least some have arrived 7 juz and some are in grade 56 this has reached 20 juz

From the journey of the Madrasah Ibtidaiyah Tarbiyatul Islam school, this Pesantren Madinatul Quran initiated the establishment of Madrasah Ulya to focus more on children and students to memorize other things then they go to school at an equality Madrasah either from the level of Ibtidaiyah Yani again or SMP And hopefully in the future there will be an equivalent madrasah for college level or at Alia's level thus eating the regulations which are currently also supported by the education law in this case and the Ministry of Religion that Madrasah Diniyah came home I stopped and then Diniyah Al could continue Ali to the campus level and all this in Indonesian context has been going well and scholars who graduate from Maha Tali have received formal recognition from the Dipati government at least there is a rope in Kajen Margoyoso Pati

The challenges and obstacles that often exist in Madrasah Madinatul Qur'an Pesantrens are the problem of tahfidz teachers who must be regenerated. Madinatul Quran treats more to the Qiroati method so that the tahfid teachers who later join this Madrasah must then adjust to the process, namely assistance for the ability of 
the Kirana method so that students get the same references and methods from their teachers. Another challenge is the Pesantren building. And for Pesantrens, which at least until 2020 are still experiencing lack of money. this is subsidized or other individual funding from the apostles from donations who are active and have concern for the Tahfidz Pesantren.

The pesantren, which is located in Pati, to be precise, in the northern Java Pesantren, is a new pesantren, although this pesantren has experienced significant development due to several factors. From the data presented by its founders, this pesantren has experienced rapid progress due to, the first is because of the ownership of a strong vision that has been built from long-term anxiety. The ups and downs of pioneering and advancing this institution become a commitment with its administrators. Second, there is an integrated learning of children both in madrasah ibtidaiyah at their formal schools and at any other times students are also able to memorize the Koran well.

The results of the evaluation carried out by the management admitted that there are problems with the children's unsynchronization, both in terms of the variety of domicile, the availability of time to the distribution of school hours, and even the unoptimistic views of formal school educators when students memorizing Koran, they are not often experiencing fatigue, drowsiness and other less encouraging behaviors when studying in madrasah classrooms.

Another progression of this pesantren is the existence of a sustainable student funding support factor. This is because the students who are less able to be supported by ZIS funds are managed by the institution "Rumah KIIITA or other donors who volunteer to help finance and build pesantren facilities. Another fourth advantage of this boarding school which is developing well in the South Pati area is the availability of the educators, both in the religious field or asaatid who teach tahfidz. They are concerned about waiting for the students and they have good competence in terms of the Koran or from the side of other teaching abilities. Thus this condition has an impact on children who feel intensive guidance and assistance in memorizing the Quran or studying other religions at Pesantrens.

As a global challenge for the Tahfidz Pesantren, especially for those who then have a focus on tahfid for young students, is the concentration of the Quranic tahfidz 
which is important in today's digital era. This is because of the importance of building integrity and good mentality in children from an early age and equipping them with the Koran which is not only memorized, but understood and internalized in the practices taught during the pesantren as a guide to the life of the afterlife.

At a higher reach, building a civilized society, building a civil society that is expected, is very much needed by generations who have understood and memorized the Koran from an early age and at an advanced stage, until they go to college, these generations can continue in competency fields more in the field of science science and technology. Thus the integrity of society's needs for the advancement of science for higher civilization is more capable and easier to materialize, when it is supported by generations that have been prepared from an early age. This Pesantren Madinatul Quran seems to have a vision of building a Quranic society seen from various indicators of educational construction or curricula that have been initiated and guarded from the start.

\section{Conclusion}

Pesantren are at the central point in educating generations because they have the effectiveness of learning to fully educate children or students in a well-ordered space and time. Pesantrens integrated with formal school learning or equality schools are becoming more intensive in the process of educating students, because there is a continuity of curriculum or integration of teachers and stakeholders in the pesantren institution. The comfort and sincerity of the students are more achieved by the ease of learning procedures or continuity in the learning room, both formal in the morning or informal in the Quranic tahfidz curriculum. This Pesantren Madinatul Quran is one of the pesantren concerned with the education of students at this establishment level, namely primary and middle schools and in its development it has a vision of building at a higher level, there are many facilitation factors and include constraints in the process of institutional development, however. the integration of various institutions both from the youth of Rumah Kiita, madrasah ibtidaiyah and equality schools and pesantren is an inspiration and one that can be a reference for special educational institutions on the concentration of religion and Qur'anic recitation. Further research research is needed in the 
framework of deepening and presenting data analysis of educational institutions that are integrated with other institutions both formal and social institutions, so that Pesantrens become more effective and superior in preparing generations to be the best of the people.

\section{References}

Al-Azami, M.M. (2005). The History of The Quranic Text From Revelation To Compilation (A Comparative Study With the Old and New Testaments). Jakarta: Gema Insani

Al-Lahim, K. (2008). Mengapa Saya Menghafal Al-Qur'an. Surakarta: Daar An-Naba.

Aly, H. N. (1999). Ilmu Pendidikan Islam, Jakarta: Logos.

Arikunto, S. (2013). Prosedur Penelitian (Suatu Pendekatan Praktik). Jakarta: Rineka Cipta.

As-Sirjani, R., Khalid, A.A. (2013). Cara Cerdas Hafal AL-Qur'an. Solo: Aqwam.

Badwilan, A.S. (2009). Panduan Cepat Menghafal Al-Qur'an. Yogyakarta: Diva Press.

Chali, M. (1952). Al-Qur'an Dari Masa Ke Masa. Semarang: C.V Ramadhani.

Dhofier, Z. (1982). Tradisi Pesantren, Jakarta: LP3E.

Djaelani, H. A. K. (2001). Konsepsi Pendidikan Agama Islam dalam Era Globalisasi, Jakarta: Putra Harapan.

Fadjar, A. M. (1998). Madrasah dan Tantangan Modernitas. Bandung: Mizan.

Fadjar, A. M. (1999). Reformasi Pendidikan Islam, Jakarta: Fajar Dunia.

Hannan, A. (2018). Islam moderat dan tradisi popular pesantren: Strategi penguatan Islam moderat di kalangan masyarakat Madura melalui nilai tradisi popular Islam berbasis pesantren, Departemen Sosiologi, Fakultas Ilmu Sosial dan Ilmu Politik, Universitas Airlangga Surabaya, Jawa Timur, Indonesia.

Hasbullah. (2001). Sejarah Pendidikan Islam di Indonesia, Jakarta: PT. Raja Grafindo Persada.

Mubarok, A.Z.S. (2020). Prospek Nazhir Wakaf Global Berbasis Pesantren di Era Digital Nazhir Prospect of Global Waqf Based on Pesantren (Pesantrens) in the Digital Era, Jurnal Bimas Islam Vol 13 No. 1.

Muhajir, N. (1998). Metodologi Penelitian Kualitatif. Yogyakarta: Rake Sarasin.

Munjahid. (2000). Strategi Menghafal Al-Qur'an 10 Bulan Khatam. Yogyakarta: Idea Press.

Nawawi, I. (1996). Menjaga Kemuliaan Al-Qur'an. Bandung: Al-Bayan.

Rahman, F. (1985). Islam dan Modernitas tentang Transformasi Intelektual, Terj. Ahsin Mohammad, Bandung: Pustaka. 
Rauf, A., Aziz, A. (2015). Kiat Sukses Menjadi Hafidz Al-Quran Daiyah (Menghafal AlQuran itu Mudah). Jakarta: Markaz Al-Qur"an.

Sarijo, M. (1980). Sejarah Pondok Pesantren di Indonesia. Jakarta: Dharma Bakti.

Sudiro, M. I. (1995). Pendidikan Agama dalam Masyarakat Modern, Seminar dan Lokakarya Nasional Revitalisasi Pendidikan Luar Sekolah dalam Masyarakat Modern, Cirebon, Tanggal, 30 Agustus - 1 September.

Sugianto, I. A. (1994). Kiat Praktis Menghafal Al-Qur'an. Bandung: Mujahid Press.

Suma, M. A. (2014). Ulumul Qur'an. Jakarta: PT Raja Grafindo Persada.

Suroyo. (1991). Perbagai Persoalan Pendidikan; Pendidikan Nasional dan Pendidikan Islam di Indonesia. Jurnal Pendidikan Islam, Kajian tentang Konsep Pendidikan Islam, Problem dan Prospeknya, Volume 1 Nomor 1

Suryabrata, S. (2009). Metode Penelitian. Jakarta: Raja Grafindo Persada.

Tadjab. (2000). Perbandingan Pendidikan. Surabaya: Karya Abditama.

Thoha, C., Muth'i, A. (1998). PBM-PAI di Sekolah: Eksistensi dan Proses Belajar Mengajar Pendidikan Agama Islam. Yogyakarta: Pustaka Pelajar bekerja sama dengan Fak. Tarbiyah lAIN Walisongo Sernarang

Wahid, R. A. (1994). Ulumul Qur'an. Jakarta: PT Raja Grafindo Persada.

Yumnah, S. (2020). Implementasi Pendidikan Islam Moderat Di Pondok Pesantren Bayt Al-Hikmah Kota Pasuruan. PANCAWAHANA: Jurnal Studi Islam Vol.15, No.1.

Zuhdi, M. (1993). Pengantar Ulumul Qur'an. Surabaya: PT. Bina I 